\title{
A combined observational and modeling approach to study modern dust transport from the Patagonia desert to East Antarctica
}

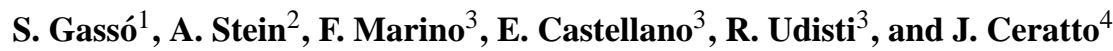 \\ ${ }^{1}$ Goddard Earth Spave and Technology, University of Maryland Baltimore County and NASA, Greenbelt, Maryland, USA \\ ${ }^{2}$ Earth Resources Technology and Air Resource Lab-NOAA, Silver Spring, Maryland, USA \\ ${ }^{3}$ Department of Chemistry, University of Florence and Department of Physics, USA \\ ${ }^{4}$ NASA Summer Institute, Greenbelt, Maryland, USA
}

Received: 5 January 2010 - Published in Atmos. Chem. Phys. Discuss.: 25 May 2010

Revised: 25 August 2010 - Accepted: 26 August 2010 - Published: 6 September 2010

\begin{abstract}
The understanding of present atmospheric transport processes from Southern Hemisphere (SH) landmasses to Antarctica can improve the interpretation of stratigraphic data in Antarctic ice cores. In addition, long range transport can deliver key nutrients normally not available to marine ecosystems in the Southern Ocean and may trigger or enhance primary productivity. However, there is a dearth of observational based studies of dust transport in the SH.

This work aims to improve current understanding of dust transport in the SH by showing a characterization of two dust events originating in the Patagonia desert (south end of South America). The approach is based on a combined and complementary use of satellite retrievals (detectors MISR, MODIS, GLAS ,POLDER, OMI,), transport model simulation (HYSPLIT) and surface observations near the sources and aerosol measurements in Antarctica (Neumayer and Concordia sites).

Satellite imagery and visibility observations confirm dust emission in a stretch of dry lakes along the coast of the Tierra del Fuego $(\mathrm{TdF})$ island $\left(\sim 54^{\circ} \mathrm{S}\right)$ and from the shores of the Colihue Huapi lake in Central Patagonia $\left(\sim 46^{\circ} S\right)$ in February 2005. Model simulations initialized by these observations reproduce the timing of an observed increase in dust concentration at the Concordia Station and some of the observed increases in atmospheric aerosol absorption (here used as a dust proxy) in the Neumayer station. The TdF sources were the largest contributors of dust at both sites. The transit times from TdF to the Neumayer and Concordia sites are 6-7 and 9-10 days respectively. Lidar observations and model outputs coincide in placing most of the dust cloud in the boundary layer and suggest significant de-
\end{abstract}

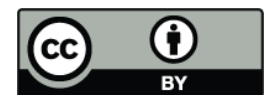

Correspondence to: S. Gassó (santiago.gasso@nasa.gov) position over the ocean immediately downwind. Boundary layer dust was detected as far as $1800 \mathrm{~km}$ from the source and $\sim 800 \mathrm{~km}$ north of the South Georgia Island over the central sub-Antarctic Atlantic Ocean. Although the analysis suggests the presence of dust at $\sim 1500 \mathrm{~km} \mathrm{SW}$ of South Africa five days after, the limited capabilities of existing satellite platforms to differentiate between aerosol types do not permit a definitive conclusion. In addition, the model simulations show dust lifting to the free troposphere as it travels south but it could not be confirmed by the satellite observations due to cloudiness.

This work demonstrates that complementary information from existing transport models, satellite and surface data can yield a consistent picture of the dust transport from the Patagonia desert to Antarctica. It also illustrates the limitation of using any of these approaches individually to characterize the transport of dust in a heavily cloudy area.

\section{Introduction}

Airborne dust can impact significantly the radiative balance of the Earth's atmosphere (Tegen et al., 1996; Sokolik et al., 2001; Miller et al., 2004). In addition it can impact marine and land ecosystems. For example, a number of studies have shown the effect of long range transport of nutrients carried by dust to the Amazon forest (Swap et al., 1992; Okin et al, 2004) as well the disruption of primary productivity in the North Atlantic (Mallet et al., 2009) by reducing solar radiation reaching the ocean surface. Long range transport of dust can supply key nutrients (Jickells et al., 2005) that stimulate primary productivity in areas where phytoplankton growth may otherwise be minimal. This is relevant in the current climate change context because oceans are responding to global warming by becoming more stratified in the upper

Published by Copernicus Publications on behalf of the European Geosciences Union. 
layers. This may prevent the surface ocean from mixing with the deep ocean, thereby decreasing the nutrient fluxes from below (Levitus et al., 2000; Sarmiento and Gruber, 2006) and affecting oceanic primary production and efficiency of $\mathrm{CO}_{2}$ transfer (Behrenfeld et al., 2006). This climate-warming induced situation makes oceanic primary production more dependent on the nutrient input from external sources, such as atmospheric deposition. This fact makes the study of the presence of dust over the Southern Ocean (40S to 60S) of particular interest because its role in the carbon cycle (it contains some of the largest $\mathrm{CO}_{2}$ sinks, Takahshi et al., 2009) and the concerns on how it would respond to a change in nutrient availability (Watson et al., 2000).

The hypothesis of dust inducing an increase in primary productivity was proposed by Martin (1990) as an explanation of the observed decrease of atmospheric $\mathrm{CO}_{2}$ with an increase deposition of dust found in ice cores at the end of the cold periods (Petit et al., 1999). In addition, dust layers in ice cores are one of the few proxies available to study paleo atmospheric transport phenomena (Fischer et al., 2007; Lambert et al., 2008). Isotopic analysis of ice cores show that the Patagonia desert was amongst the largest contributors to the dust found in East Antarctica (Basile et al., 1997; Delmonte et al., 2009). Although dust deposition was more abundant in glacial times, recent studies in snow samples in the Antarctic Peninsula (McConnell et al., 2007) and East Antarctica (Sala et al., 2008; Marino et al., 2008a; Lambert et al., 2008) indicate there has been recent deposition of dust (in the last 100 years) and it was suggested that the Patagonia desert was an important source along with Australia (Revel-Rolland et al., 2006; Marino et al., 2008a).

Much of what is known about transport of tracers in the high latitude Southern Hemisphere is known through model studies (Jickells et al., 2005; Li et al., 2008; Mahowald et al., 2009). Observational studies of aerosol transport into the Southern Ocean have been notably missing and restricted to occasional research cruises (Baker et al., 2006; Wegener et al., 2008). The high latitude marine environment is rather cloudy and dust emissions from land masses in the $\mathrm{SH}$ are sporadic and not very abundant. Both features contribute to a low probability of detection with satellite detectors because detection algorithms require clear sky pixels for dust detection. In addition, there are very few data sets of continuous aerosol monitoring in the Southern ocean region and Antarctica. Only recently and thanks to the increase of in-situ monitoring (Gaiero et al., 2003; Gaiero, 2007) and the overabundance of satellites with complementing detection capabilities, a number of combined observational and modeling studies have been published (Gassó and Stein, 2007; Fiebig et al., 2009). Also, detailed studies of modern aerosol composition in coastal and central Antarctic regions have become available recently (Udisti et al., 2004; Fattori et al., 2005; Becagli et al., 2009)

This paper presents a detailed study of two dust events originating in the south end of Patagonia. Using a combina- tion of model and satellite data analysis, this work tracks and characterizes the progression of a dust cloud over the Southern Ocean and compares the model outputs with aerosol measurements at two sites in East Antarctica.

This work is motivated by the direct observation of a sharp peak of non-sea-salt $\mathrm{Ca}^{2+}$ (nssCa, a proxy for dust, Fischer et al., 2007) deposition during a single day (9 March 2005) at the Concordia Station (75.1 S, 123.35 E; 3233 ma.s.l., Antarctica), the location of the EDC deep ice core, drilled in the framework of the EPICA (European Project for Ice Coring in Antarctica). The short period of exposure permitted the exploration of the provenance of the dust using a backtrajectory modeling approach and a detailed look at satellite imagery.

This paper is structured as follows. Section 2 details the modeling tools and data sets available and their main features and limitations, section 3 explains the approach used to analyze the data as well as a description of model outputs and observations. Section 4 summarizes and integrates the finding of Sect. 3. Section 5 discusses the main conclusions and implications of these findings.

\section{Data}

\subsection{Satellite data}

The satellite data from a number of detectors was selected for aerosol type differentiation, dust event localization and 3-D tracking after the event. The satellite data analyzed was from the detectors MODIS (Remer et al., 2005), GLAS (Spinhirne et al., 2005), MISR (Diner et al., 2001), PARASOL (Herman et al., 2005) and OMI (Torres et al., 2007). The main capabilities of these detectors have been documented elsewhere and only those features relevant for this analysis will be discussed. All satellite data used in this study were extracted from the standard products (visible images and level 2) made available for each satellite.

One important hypothesis in this study concerns the detection of aerosol type present. The high latitude southern hemisphere marine environment is mostly dominated by marine aerosols (largely derived DMS and sea salt), with occasional seasonal intrusions of dust and smoke from biomass burning (Kaufman et al., 2002). Although pollution is important in some major metropolitan areas in the mid-latitudes, these aerosols are not known for traveling long distances in the Southern Hemisphere. Large scale transport of smoke usually occurs in late August in West Africa and August to October in the Amazons with the latter is known to reach high latitudes (>60 S) occasionally (Pereira et al., 2006; Fiebig et al., 2009). During the period of interest (end of austral summer), dust is a sporadic feature in the southern hemisphere deserts and biomass burning is uncommon.

From the viewpoint of remote sensing, there are specific satellite markers that can be used to differentiate dust from 
sea-salt. For example, the Aerosol Index (AI) product from OMI (Torres et al., 2007) is sensitive to absorbing aerosols, a common characteristic of dust and not of sea-salt aerosol. MODIS fine mode fraction aerosol product (a measure of which aerosol mode is dominant) can be used as a marker for dust provided that high aerosol concentrations are present (Kaufman et al., 2002). The MISR non-spherical fraction (Kalishnikova and Khan, 2008) provides information on the fraction of aerosol optical depth that can be matched to a nonspherical aerosol model. Likewise, the POLDER aerosol algorithm produces a dust proxy called non-spherical fraction too (Herman et al., 2005).

However, all these proxies have limitations that become apparent in the southern environments. Abundant cloudiness and the resulting contamination is a major limitation that results in very few clear sky pixels. In this case, OMI and PARASOL retrievals are particularly affected. Generally speaking, retrievals near the source (usually on the day of emission and the day after) are robust if there is enough cloud clearing and aerosol concentrations are high. It is expected that the five sensors would be consistent in observing the same aerosol although they may not detect it as dust. However, the tracking of the dust as it advects is a challenging task. Dispersion and dilution of the dust cloud results in low aerosol concentrations and very low reflectances reaching the satellite sensor. Further some of the aerosol type proxies retrieved have not been compared or established their range of validity by comparing with independent measurements(AI, non-spherical parameters from PARASOL and MISR). Other like the MODIS fine mode fraction and Aerosol Index product has been widely used and compared against observations (Kleidman et al., 2005).

All satellite data products were used at level 2, that is, non-gridded native parameter product except in the case of PARASOL. The data analyzed was processed by the respective science teams using the following data algorithm versions: MODIS: collection 5, MISR: version 12 (F12_0022), OMI: collection 3, PARASOL: Gridded atmospheric product, software version 10.5, GLAS: version 2.8.

\subsection{Surface data}

Different sources of surface data were used in this analysis. Model outputs were compared with surface measurements of aerosols at two sites in Antarctica. In addition, the model simulations were initialized and constrained by meteorological information from several weather stations along the coast of Patagonia. These data sets are described next.

\subsubsection{Concordia Station in Antarctica}

The Concordia Station (75.1 S, 123.35E; 3233 ma.s.l., Antarctica) is part of the EPICA (European Project for Ice Coring in Antarctica) project and it is where Dome C deep ice core has been drilled. A long term aerosol monitoring program is active since 2004. The program consists on the collection of aerosol samples at different temporal resolution, with and without particle size separation, in order to obtain highly detailed information on aerosol chemical and physical properties, as well as changes in transport and deposition patterns in different seasons (Becagli et al., 2009). The study of mechanisms of present-day aerosols transport and deposition is basic for the correct interpretation of icecore proxies, among which dust constitutes one of the most studied (Lambert et al., 2008). Rapid events of dust transport to Dome $\mathrm{C}$ are studied by measuring $\mathrm{nssCa}$ as soluble proxy of dust in aerosol samples collected at higher temporal resolution (from daily to weekly). $\mathrm{NssCa}^{2+}$ concentrations in ice cores are commonly used to infer information about terrestrial inputs in polar regions (Wolff et al., 2006), even if the quantitative relationship between $\mathrm{nssCa}^{2+}$ and dust are not fully defined for different climatic regimes, depending on dust mineralogy (e.g. Bigler et al., 2006; Ruth et al., 2008); however nssCa ${ }^{2+}$ is calculated from $\mathrm{Na}^{+}$and $\mathrm{Ca}^{2+}$ concentrations (using the formula $\mathrm{nssCa}^{2+}=\mathrm{Ca}^{2+}-$ $\left(\mathrm{Ca}^{2+} / \mathrm{Na}^{+}\right) \mathrm{sw} * \mathrm{Na}^{+}$, where sw stays for sea water), measured with high sensitivity in ice and aerosol samples by Ion Chromatography (Morganti et al., 2007). Data presented in this work come from $\mathrm{nssCa}^{2+}$ measurements performed on aerosol samples collected by 8 -stage Andersen impactor for size-resolved (from 0.4 to $10 \mu \mathrm{m}$ ) aerosol collection. Filters are exposed every one or two weeks using a pumping volume of about $28.31 \mathrm{~min}^{-1}$. Data plotted in Fig. 1 refer to the sum of $\mathrm{nssCa}^{2+}$ concentrations in the 8 stages, i.e. they constitute the atmospheric concentration of $\mathrm{nssCa}^{2+}$ soluble fraction of particulate in the range $0.4-10 \mu \mathrm{m}$. In the particular case of the main event of dust deposition studied here, aerosol collection started at about 3 p.m. (Dome Concordia local time, i.e. UTC +7) of 8 March, and ended approximately the day after (9 March) at the same time. On 9 March 2005, operators had to stop sampling operations temporarily for instrument maintenance and removed filters which had been installed just $24 \mathrm{~h}$ before. The sampling resumed normally after a few days. During the post campaign analysis, an anomalous peak in nssCa was detected in all the filters exposed in that $24 \mathrm{hrs}$ period (largest concentration seen in Fig. 1).

\subsubsection{Neumayer surface station in Antarctica}

The Alfred Wegener Institute for Polar and Marine Research (AWI) runs a permanently manned Georg-von-NeumayerStation (70.65 S, $8.25 \mathrm{~W}, 36 \mathrm{~m}$ a.s.l) at the northwest edge of the Weddell Sea in Antarctica. It is part of the WMO Global Watch Stations (König-Langlo and Weller, 2006). Aerosol sampling was made at the Air Chemistry Observatory, about $1.5 \mathrm{~km}$ south of Neumayer station. Weller et al. (2008a) reported surface measurements of aerosol number concentration, optical properties (scattering and absorption coefficients, angstrom exponent) and limited chemical composition. The data was reported as daily averages from January, 


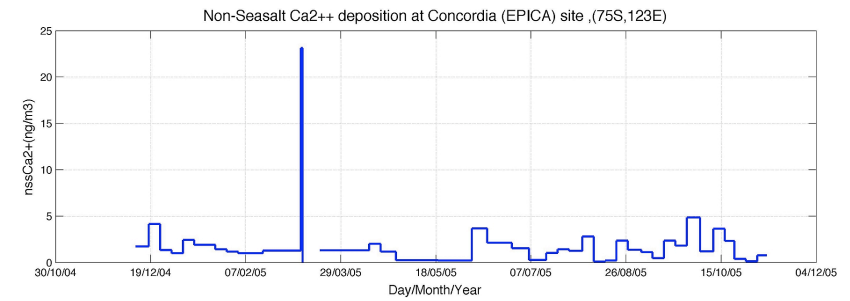

Fig. 1. Non sea-salt calcium extracted from airborne aerosols measured at the Concordia Station site (Dome C, Concordia project) during the 2004-2005 campaign. The largest peak corresponds to a $24 \mathrm{~h}$ filter measurement from 09:00 UTC 8 March 2005 to 08:00 UTC 9 March 2005.

2004 to December, 2006. The version of data used in this study is the one available at the free public archive Pangea (Weller et al., 2008b). Because no specific chemical analyses for dust were available at Neumayer, the aerosol absorption coefficient can be used as proxy of dust if making reasonable assumptions. Dust is more absorbing than marine aerosols (Dubovik et al., 2002) resulting in a higher absorption coefficient. The main hypothesis then is that amongst the atmospheric aerosols measured at Neumayer dust is the only absorbing one. However, it should be noted that smoke, another absorbing aerosol, from South America has been observed in Antarctica (Pereira et al., 2006; Fiebig et al., 2009). This fact is considered in the analysis section below.

\subsubsection{Surface meteorological observations}

Weather meteorological stations located at several airports in Patagonia routinely monitor visibility conditions and standard environmental variables in support of aircraft activity. These observations are carried out by operators who report a quantitative measure of sky turbidity (visibility ,measured in kilometers or miles) and a code that identifies the state of the sky (such as the presence of precipitation, haze, smoke, etc.) . Dust events are explicitly reported. The data used to constrain the model simulations in this analysis is from the stations Comodoro Rivadavia (abbreviated CR and located at $45.8 \mathrm{~S}, 67.5 \mathrm{~W}, 46 \mathrm{~m}$ a.s.l.) and Río Grande (abbreviated $\mathrm{TdF}$ and located in the island of Tierra del Fuego, $53.8 \mathrm{~S}, 67.8 \mathrm{~W}, 22 \mathrm{~m}$ a.s.l). In addition, visibility data from the following stations was checked for dust activity: Bahía Blanca, Trelew, Puerto Deseado, San Julián and Río Gallegos. Visibility reports from meteorological stations constitute one of the longest record of modern dust activity and it can be used for dust trend studies (Mahowald et al., 2007). In this case, surface visibility information is used to obtain an independent confirmation of dust activity and the duration of the event. It should be noted that even though the station data is available NOAA's National Climatic Data Center (http://www.ncdc.noaa.gov/oa/ncdc.html), the data used in this analysis was obtained directly from the argentine weather bureau (Servicio Meteorológico Nacional or SMN). The SMN data has the highest time resolution of observations (usually every hour) whereas not all the stations had the same time resolution at the NCDC archive. The use of higher temporal resolution made possible to resolve dust events of short duration.

\subsection{Hysplit model}

The HYSPLIT model (version 4.8) is a lagrangian transport model frequently used for trajectory analysis and dust and smoke forecasts (Draxler et al., 2001; Draxler and Rolf, 2003). The reader is referred to Draxler and Hess (1998) for more details on the model and only those features relevant to this study are highlighted here. HYSPLIT uses the meteorological fields from the NCEP's Global Data Assimilation Scheme (GDAS) (Kanimatsu, 1989; Kalnay et al., 1996) at $1 \mathrm{x} 1$ degree resolution. Dust emission is based on the threshold friction velocity approach where surface roughness is correlated with soil properties. When the local wind speed exceeds the threshold velocity for the soil type of that emission cell (Escudero et al., 2006), the dust emission rate is computed. The model domain was set to the southern hemisphere (0-90 S, $180 \mathrm{~W}$ to $180 \mathrm{E})$ at $1 \mathrm{x} 1$ degree resolution. In addition to the default dust emission parameters, the model allows the user to set a number of parameters such as size and intensity of the source and duration of emission. Model runs divided the atmosphere in 8 layers from 0 to $10 \mathrm{~km}$. As explained later in Sect. 3.1, all these options were set based on satellite and surface meteorological information. A few test runs determined that for a number of particles higher than $2 \times 10^{5}$, the distribution of concentrations did not change and all runs used this number of released particles. A time step of computation of $12 \mathrm{~min}$ was used and output concentrations at surface and total in the column were saved at 1 hour intervals. The results are reported as number of particles per unit of volume in the layer or integrated over the column.

It should be noted that model runs are used to indicate the location and distribution of the dust cloud as it propagates and to estimate the travel times to Antarctica. Because the unknown actual deposition rates, quantitative comparisons between model and in-situ/satellite retrievals will be avoided. However, some relative quantitative comparisons between the different runs will be shown to point out the strength of the sources and their relative contribution to each site.

\section{The modeling of dust events}

\subsection{Identification of dust sources}

In order to determine the source regions, back-trajectories modeling runs were carried out from 9 March to 25 February for air masses arriving to Dome C. Air masses were over the east coast of Patagonia, over the south tip of South Africa and over the south coast of Australia by 26 February. In order 
to verify whether any of those areas were actively producing dust in the same time frame, the OMI AI, visible images and optical depths of MODIS were analyzed on these three areas. Three dust events were identified. One of them was in Central Australia near lake Eire (28.86 S, 139.13 E) on 2 March (see Aqua granule 03:05 UTC). This event was simulated by HYSPLIT in forward mode. The model run showed that air masses leaving Central Australia on 2 March advected east and did not reach Concordia. Thus, most likely Australia did not contribute to the dust measured at Concordia on 9 March.

The other two dust events were observed in the Patagonia desert. Dust plumes were detected by MODIS on 26 February 2005 (Fig. 2, Aqua granule 18:00) leaving the area of dry lakes between the city of Río Grande (53.86 S, $67.76 \mathrm{~W})$ and the San Sebastián Gulf in the island of Tierra del Fuego (about $90 \mathrm{~km}$ North of Rio Grande). The sources at the San Sebastián Gulf are deflation flats and are common in the area (Isla et al., 1991; Vilas et al., 1999) and the dry lakes north of Río Grande are of the same nature (D. Gaiero, personal communication, 2009). A large plume is observed originating in a coastal mud flat or dry lake west of the San Sebastián gulf. The longest plume visible in the image originates from this source; its length is $\sim 500 \mathrm{~km}$ and the optical depths are in the $0.35-0.45$ range, which are considered above "background" values (typically below than 0.15 ). Although not clear in this image, smaller dust plumes can be indentified north of the city of Rio Grande in the $250 \mathrm{~m}$ resolution image. This event lasted approximately $12 \mathrm{~h}$ based on the visibility reports from the meteorological station at Río Grande.

The second event occurred on 22 February and the dust originated from two different regions in Patagonia. Dust plumes were visible in MODIS (Aqua granule 18:30) imagery originating at the shores of lake Colihue Huapi, (45.65 S, 68.75 W), west of the Comodoro Rivadavia seaport. The source area has been identified as extremely windy (Labraga, 1991) and as going through a severe desertification process (Del Valle et al., 1998). A compact patch of AODs $(\sim 0.3)$ was retrieved by MODIS over the ocean in the San Jorge Gulf (less than $100 \mathrm{~km}$ downwind from the source). The Tierra del Fuego island was cloud covered in the Aqua and Terra-MODIS images but the sea along the shore was cloudless. The MODIS aerosol product for this clear sky area showed a large group of pixels of high and homogenous aerosol optical (AOD >0.3, Aqua granule 18:25) approximately $100 \mathrm{~km}$ SE of the San Sebastián Gulf. Dust activity was confirmed by surface weather stations in both Comodoro Rivadavia and Río Grande.

No biomass burning or additional dust activity was noted in the 22 to 26 February period in the satellite imagery and in the surface meteorological observations.

\subsection{Setup of forward model runs}

Forward model runs with HYSPLIT were simulated for the 22 and 26 February dust events. The runs were initialized

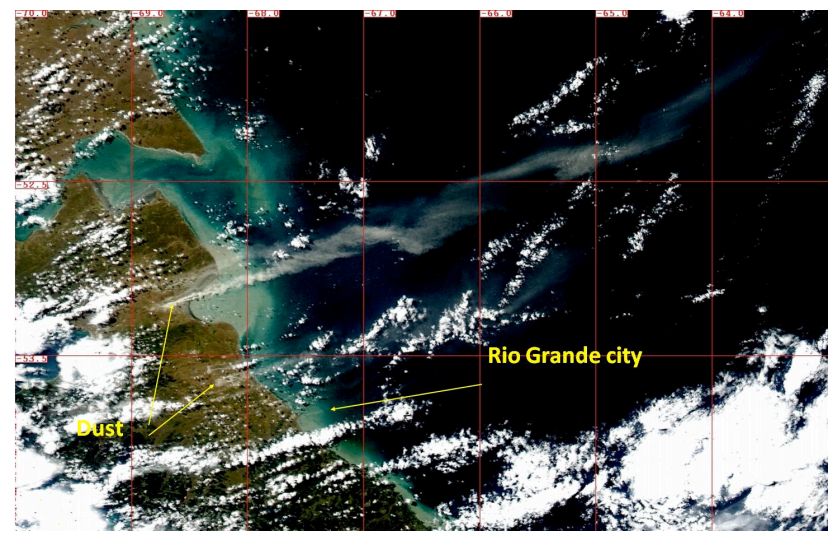

Fig. 2. Dust Event in the Tierra del Fuego Island ( $~ 53 \mathrm{~S})$ detected by MODIS in the Aqua satellite on 26 February 2005. The largest plume is in the Gulf of San Sebastian and several minor plumes (some are not resolved in this image but they are visible by zooming in the full $250 \mathrm{~m}$ image) are located between San Sebastian and the city of Rio Grande, $100 \mathrm{~km}$ south.

with the information from the known (observed) dust sources and the duration of event. The exact location and the area of the dust sources were digitized from the MODIS images. High-resolution MODIS images $(250 \mathrm{~m})$ were used to locate each dust emitting lake. The source was identified using Google Earth (GE) and then a polygon was drawn over the identified sources. If the MODIS image was clear enough, the section of the lake emitting dust was drawn (for example, a shore of a lake). Otherwise, the whole area of the lake was drawn and it was assumed that the whole lake was active. Then, the area of the polygon was computed and used as one of the inputs for initialization of the model simulations. The advantage of this approach resides in model runs based on identified active sources and the length of time of emission is based on the weather station reports of observed dust. There is, of course, an error in estimating the active area in the GE imagery based on the dust activity seen in the MODIS image. For example, the edges of the sources in the GE image database may not correspond to the edges of the active sources in MODIS. These differences are assumed to be small. Table 1 details the location of each source identified in the MODIS Terra and Aqua image and their respective area in square kilometers.

The duration of each event was set by the number of hours where any amount of dust was observed (i.e. World Meteorological Organization METOP codes 6-9) by the closest meteorological station to the source. None of the stations reported a "dust storm" (code 9) and most corresponded to codes 6 and 7 (low and moderate dust in the air). For each group of active sources identified, a HYSPLIT run in forward mode was carried out. These runs are identified as Feb22TdF, Feb26TdF and Feb22CR corresponding to dust leaving Tierra del Fuego on 22 and 26 February and 
Table 1. Location and description of dust activity and sources as seen in MODIS visible images (observation time noted as "granules"). In all cases when it was not clear if dust is coming from the edge of the source, the estimated area of emission was to be the totality of the lake/depression.

\begin{tabular}{|c|c|c|c|c|}
\hline Date & \multicolumn{2}{|c|}{$22 / \mathrm{Feb} / 2005$} & Terra granule & 14:20 UTC \\
\hline $\begin{array}{l}-45.66 \\
-53.23 \\
-53.09 \\
-53.63\end{array}$ & $\begin{array}{l}-68.66 \\
-68.68 \\
-68.58 \\
-68.15\end{array}$ & $\begin{array}{l}40.194 \\
15.7180 \\
2.2161 \\
6.8615\end{array}$ & \multicolumn{2}{|c|}{$\begin{array}{l}\text { Patagonia is located in center of MODIS swath, providing good detail. Area is generally cloudy, } \\
\text { with a clear area extending from Comodoro Rivadavia to Puerto Santa Cruz. North end of } \\
\text { Tierra del Fuego is partly cloudy. Small lakes appear to have minimal dust activity. }\end{array}$} \\
\hline Latitude & Longitude & Area $\left(\mathrm{km}^{2}\right)$ & Remarks & \\
\hline-45.66 & -68.66 & 40.194 & $\begin{array}{l}\text { 18:30 UTC: } \mathrm{C} \\
\text { same source } \mathrm{s} \\
\text { of image and } \\
\text { the coast of } \mathrm{Ti}\end{array}$ & $\begin{array}{l}\text { dust cloud off the coast of Comodoro Rivadavia. Some dust activity from } \\
\text { in Terra. 18:25 UTC: Area of interest is located on the far western edge } \\
\text { mostly obscured by patchy clouds south of San Jorge Gulf. Clear sky off } \\
\text { a del Fuego. Dust off the coast of Río Grande. }\end{array}$ \\
\hline $\begin{array}{l}-53.23 \\
-53.66 \\
-53.78 \\
-53.86 \\
-53.18 \\
-53.58\end{array}$ & $\begin{array}{l}-68.68 \\
-68.26 \\
-67.79 \\
-67.62 \\
-69.11 \\
-68.34\end{array}$ & $\begin{array}{l}15.7180 \\
7.5952 \\
2.3015 \\
9.2771 \\
9.4524 \\
4.2668\end{array}$ & \multicolumn{2}{|c|}{$\begin{array}{l}\text { Clear sky view over Tierra del Fuego but towards the west edge of then MODIS swath, causing } \\
\text { slight loss of detail. }\end{array}$} \\
\hline Date & \multicolumn{2}{|c|}{$26 / \mathrm{Feb} / 2005$} & Aqua granule & 18:00 and 19:40 UTC \\
\hline Latitude & Longitude & Area $\left(\mathrm{km}^{2}\right)$ & Remarks & \\
\hline $\begin{array}{l}-53.23 \\
-53.66 \\
-53.78 \\
-53.18 \\
-53.58\end{array}$ & $\begin{array}{l}-68.68 \\
-68.26 \\
-67.79 \\
-69.11 \\
-68.34\end{array}$ & $\begin{array}{l}15.7180 \\
7.5952 \\
2.3015 \\
9.4524 \\
4.2668\end{array}$ & \multicolumn{2}{|c|}{$\begin{array}{l}\text { Area of interest is located on the far western edge of the MODIS swath for 18:00 image, and on } \\
\text { the far eastern edge for the 19:40 image. Patchy cumulus clouds in the area of } \\
\text { Tierra del Fuego. Most of sources are visible. }\end{array}$} \\
\hline
\end{tabular}

Comodoro Rivadavia on 26 February. The duration of emission is set to the time frame of dust activity as reported by the surface observations. These runs are referred as "constrained runs". In order to test the impact of initializing the runs with observations, three additional runs for the same group of sources was carried out, with the default dust emission enabled i.e. sources become active when the threshold wind speed is reached any time between at 00:00 and 24:00 UTC on 22 and 26 February. These runs are referred as "unconstrained runs". Thus a total of six model runs were carried out.

According to the weather observations in Río Grande airport on 26 February, dust was observed from 13 (local time $=$ UTC- $4 \mathrm{~h}$ ) until $24 \mathrm{~h}$ (local time) with visibilities ranging $2-8 \mathrm{~km}$ in the first $8 \mathrm{~h}$. The weather code assigned to this event was 7 which is "dust in the air", that is, it was not identified as dust storm. Wind direction was from the west and averaged 40 to $50 \mathrm{~km} / \mathrm{h}$ and gusts reached $75 \mathrm{~km} / \mathrm{h}$. Then, the constrained simulations of HYSPLIT used a window of $11 \mathrm{~h}$ for active dust emission. Note that it is unknown for how long the largest source at San Sebastián was active since the weather station was too far to see this plume and visibility reports were most likely based on dust activity in local lakes. However, it was active between 14:00 and 19:40 UTC since dust emission was clear in the MODIS images.

As opposed to 26 February, most of Tierra del Fuego was cloud covered on 22 February during both Terra and Aqua passes. However, the MODIS aerosol retrieval algorithm detected an aerosol cloud in the cloudless area near the shore of Tierra del Fuego. In addition, the Río Grande meteorological station reported reduced visibility by dust from 14 to $19 \mathrm{~h}$ local time with wind speeds ranging from $50-60 \mathrm{~km} / \mathrm{h}$ and wind gusts ranging 75 to $95 \mathrm{~km} / \mathrm{h}$. Since it was cloudy, there is no visual imagery to confirm the location of active sources. 


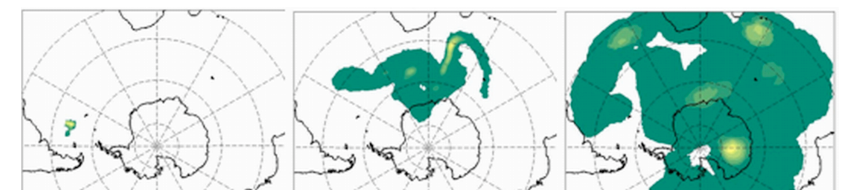

Fig. 3. Total columnar dust concentrations modeled by HYSPLIT initialized by the active dust sources detected by MODIS on 26 February 2005 and emission duration constrained by surface visibility measurements. Outputs are shown for 27 February (left), 3 March (center) and 9 March (right). Lighter colors indicate higher concentrations.

Thus the model runs assumed the same active sources visible in a previous dust event in the same area (16 January) which are very close in size and proximity to those seen active on 26 February. The Colihue Huapi lake area was clear of clouds in the MODIS Aqua image (granule 18:30 UTC) and there was positive identification of dust emission from the eastern shores of the lake. The Comodoro Rivadavia weather station, located just downwind of the Colihue Huapi lake, reported dust activity from 13 to $20 \mathrm{~h}$ local with gusts in the 65 to $85 \mathrm{~km} / \mathrm{h}$ range during the period. Overall and according to surface observations, it appears the dust event of 26 February was the most intense and the longest amongst the three events.

Although in the reminder of the paper the constrained runs will be used for comparison with satellite and surface data, there were some differences between the two modes of emission that will be noted.

\subsection{Propagation of the modeled dust cloud}

Figure 3 shows normalized total columnar concentrations for the case Feb26TdF for 2, 6 and 11 days after the event. The rapid progression is apparent on the second day after emission with the leading edge located $+1000 \mathrm{~km}$ from the source. By the 5th day, the dust cloud had reached over the area between South Africa and Antarctica and the leading east edge had reached Kerguelen Islands (70 E) area. The south end of the cloud is entering Antarctica at $\sim 20 \mathrm{E}$. By the 11th day, the dust covered most of the Antarctica plateau. It should be noted that after the 5th day, the dust has dispersed and diluted significantly and the area covered is very large. This is not necessarily is a proof of actual dust transport to that point since the removal processes are poorly parameterized in models (see for example Xian et al., 2009) and it is unknown how much material removed from the column. However, the model output does provide an envelope of maximum expansion of the dust cloud and a minimum travel times under the ideal condition of no removal events.
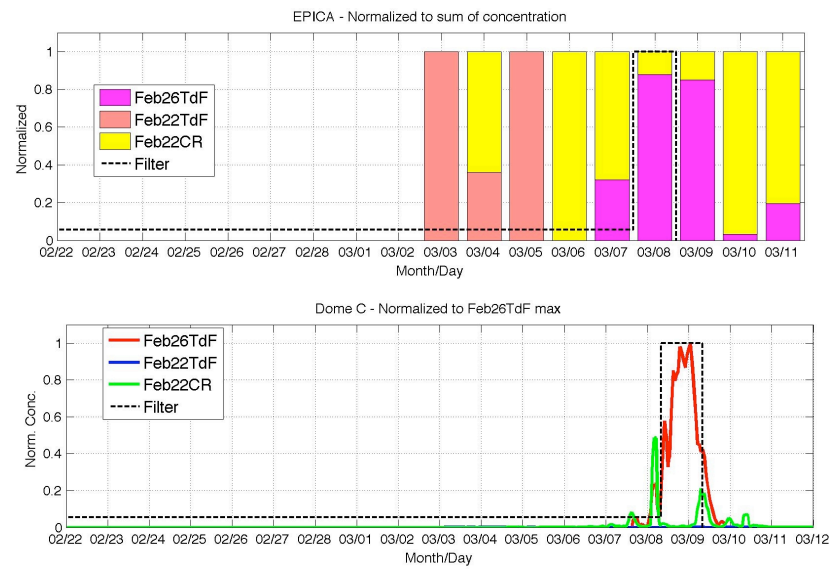

Fig. 4. Time of HYSPLIT surface concentrations at Concordia (123 E, $75 \mathrm{~S}$ ) for 3 dust events described in text and the dashed black line is the nss-Ca filter measurement at Dome C. Top: the contribution of each run to the total concentration for that day and Bottom: Surface concentrations normalized to the maximum of Feb26TdF. Top figure illustrates the relative contribution of each dust event. Bottom figure shows that most of the dust arriving to Dome $\mathrm{C}$ on 8 March originated in Tierra del Fuego on 26 February.

\subsection{Comparison with surface measurements}

A comparison of model outputs with surface measurements are shown in Fig. $4 \mathrm{a}-\mathrm{b}$ where a time series of the dust concentrations from the lowest layer at the Concordia site for the three constrained simulations is displayed. Figure 4a shows the contribution of each source to the total dust concentration at the site (modeled data is aggregated to $24 \mathrm{~h}$ intervals). Figure $4 \mathrm{~b}$ shows all runs normalized to the maximum value of the Feb26Td run. The dashed line is the normalized surface measurement of nss-Ca at Concordia.

Figure 4a shows that dust from event Feb22TdF starts to arrive on 3 March and for event Feb22CR arrives in full on 6 March. The different travel time of the two sources ( $\sim 9$ days and $\sim 12$ days respectively) is a consequence of the different location of the sources ( $+800 \mathrm{~km}$ apart). In particular, dust from Comodoro Rivadavia has to cross the storm track where emission in Tierra del Fuego is already emitted at the track's path or south of it. It takes $\sim 9$ days of travel time for the event Feb26TdF too.

Most notably, the maximum amount of dust arriving for run Feb26TdF occurs during most of the day on 8 March that it is, during the $24 \mathrm{~h}$ filter exposure at the site. The Feb26TdF event contributed much more dust to the Concordia site than any of the other two events. Figure 4a shows that the 22 February events contributed most of the dust arriving to Concordia prior to 8 March but the amount contributed by this event appear to be minimal when compared to the other two events. According to the model, the concentrations from Feb22TdF were always $2-3$ or more orders of 

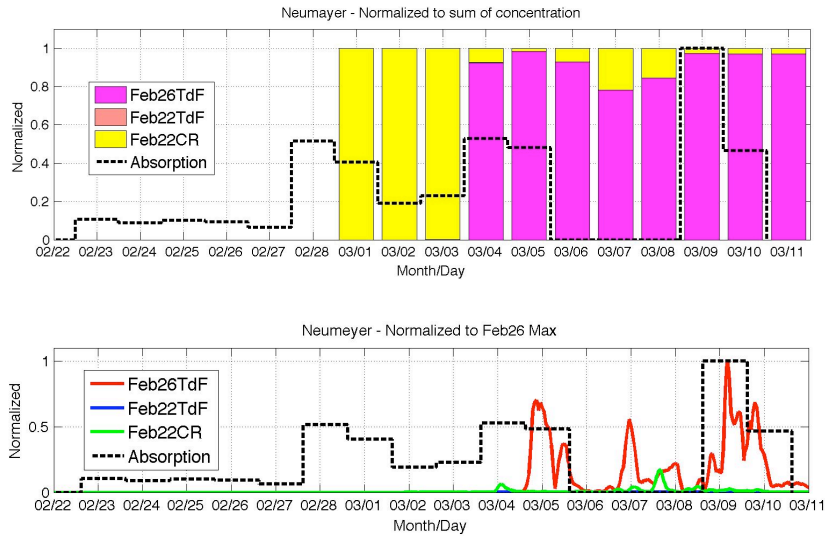

Fig. 5. Time series of HYSPLIT surface concentrations at Neumeyer for the 3 simulated dust events described in text and the black line is the normalized aerosol absorption coefficient measurement at the site. Top plot: the contribution of each run to the total concentration for that day and bottom: concentrations normalized to the maximum of Feb26TdF. The 26 February event correlates with increases in absorption on 5 and 9 March. Dust from the Feb22CR event arrives earlier to Nuemayer (1 March).

magnitude than the other two cases (this is the reason why there is no visible blue line in Fig. 4b).

Figure 5 shows a similar time series for the Neumayer station. In this case, comparisons are not as clear cut. Aerosol absorption observations (black dashed line) are normalized to the 9 March value and indicate the presence of three peaks (28 February-1 March, 4-5 and 9-10 March). According to the model runs, dust from two sources (Feb22CR and Feb26TdF) arrive on 4 and 9 March and they coincide with an increase in aerosol absorption (Fig. 5a). However, note that model runs show dust from Feb22CR and Feb26TdF arriving on 7 March too but no corresponding increase in absorption is observed and there is no coincidence with the 28 February-1 March peaks either. Figure 5b shows the same model data but normalized to the maximum value of the Feb26TdF for the corresponding day. After 3 March, dust from Feb26TdF is the dominant contributor to Neumayer and $\mathrm{CR}$ was a minor contributor. Like in the previous comparison, the Feb22TdF contribution with respect to the other larger events is minimal. In addition, the lack of coincide between some of the peaks suggests that additional absorbing aerosols other than dust reached Neumayer in this period.

This travel time may appear long if considering that the Neumayer is relatively close to Patagonia (compared to Concordia). However, inspection of the modeled trajectories for each of the three cases shows that none of them follows a straight meridional transport. This transport pattern is common in the high latitude SH where moisture fluxes into Antarctica follow the motion of cyclonic systems (Jones and Simmonds, 1993; Rassmussen and Turner, 2003). In all three cases the dust cloud is advected east and then it veered south and then west arriving to Neumayer from the NE (see for example Fig. 3, center). This path results in a longer transport time than would be expected if going in a more or less straight line from Patagonia to Neumayer. This transport pattern is partially confirmed by the satellite imagery (see next section).

These two comparisons suggest that dust leaving Tierra del Fuego on 26 February contributed most of the dust observed in Dome C on 8 March and it was the largest contributor to the aerosol absorption measured in Neumayer after 3 March. Although the sources at Comodoro Rivadavia have larger emission area than Tierra del Fuego, it appears the proximity to Antarctica makes the latter region a more effective source of dust in quantitative terms. The travel times to Neumayer for the Feb22TdF and Feb22CR and Feb26TdF runs are $\sim 7, \sim 11$ and $\sim 6$ days respectively.

Figure $4 \mathrm{a}$ illustrates another interesting point. If significant amounts of dust leaving Tierra del Fuego on 26 February reached Antarctica, why did not the case of Feb22TdF show a similar pattern? Since both runs had sources of similar size, the other two controlling parameters of dust emitted in the model are wind speed and the length of time exceeding the threshold velocity. The amount of dust generated is proportional to a power function of the wind and small differences in wind speeds have a non-linear effect and large variations in dust production. Assimilated wind fields and measured surface winds at the Rio Grande station agree in showing more intense winds and longer emission times on 26 February than on the 22nd that is, the model produced more quantities of dust on 26 February. Thus, under the assumption that in both events the removal rates of dust were similar during the transit to Concordia, the number of hours of wind speeds above the threshold velocity are the critical parameters in making the Feb26TdF event the major dust contributor.

The comparison of assimilated wind speeds (GDAS data base) in HYSPLIT for the grid point corresponding to Rio Grande station with the measured winds at the same site shows that high winds start earlier in the assimilated winds than at the surface station. This time difference in the initiation of high winds impacts the dust production of the unconstrained and constrained model runs. The unconstrained runs emit larger quantities of dust and earlier than in the constrained runs. These differences do not appear to have an impact on the travel times to Neumayer and Concordia. However, the differences become obvious when comparing with satellite as it is shown in the next section.

\section{The satellite record}

The previous section showed that dust leaving Patagonia can reach sites in Antarctica more than $5000 \mathrm{~km}$ from the source. However, the long time difference between emission and arrival to the Antarctica sites as well as the poor characterization of the removal processes commonly found in transport 


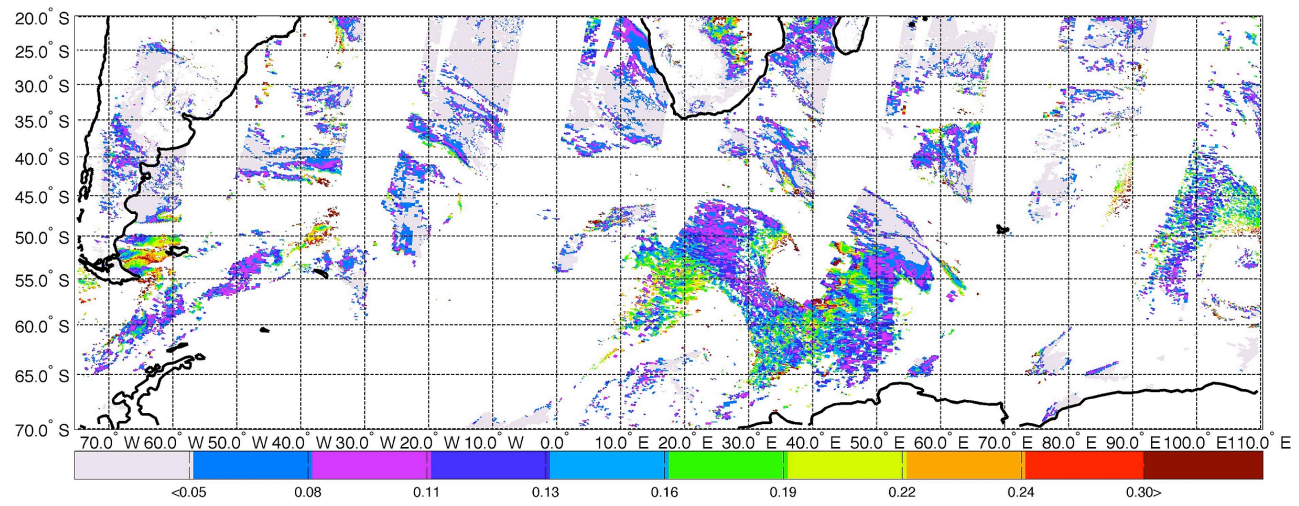

Fig. 6. Hemispherical map aerosol optical depths from Terra MODIS on 26 February 2005. Note the adjustment of color scale by setting maximun at 0.3 in order to emphasize the variable low aerosol concentrations. The dust event from Tierra del Fuego is visible with AOTs $>0.24$ (see text).

models casts some doubts on whether the dust from Patagonia $\mathrm{c}$ an reach this area. In this section the analysis of satellite observations of the dust transport from Tierra del Fuego (26 February event) is described in detail.

\subsection{Methods}

The abundant cloudiness over the Southern Ocean (SO) is a significant shortcoming because aerosol remote sensing requires a clear sky patch (i.e. a cloudless view of the ocean) for the retrievals algorithm to operate. This is illustrated in the MODIS-Terra AOTs (Fig. 6) where large areas in the SO are devoid of aerosol retrievals because of clouds. Also, note that in order to illustrate the presence of aerosols the color scale has to be set from 0.05 to 0.3 , a range of values normally considered clear to moderate concentrations of aerosols. Further, this image includes the initial stages of the 26 February dust event in Tierra del Fuego. However, its AOT values are in the $0.2-0.3$ range and they are hardly any different to the equally high values of AOT found in the rest of the scene. Without any additional information, it is not possible to identify a plume or cloud of dust in this image. The most common aerosol types present in this region are commonly referred as "marine" aerosols. The optical properties of marine aerosols are typical of those aerosols dominated by a coarse mode resulting in low spectral dependence in the visible and low aerosol optical depths (typically below 0.15). Dust detection approaches (Kaufman et al., 2005; Yu et al., 2009) differentiate dust from seasalt by using a threshold based on the AOT magnitude. This is a reasonable assumption in environments where the abundant and constant dust emission results in high AOTs $(>0.4)$. However, they are not well suited to study low aerosol concentrations and heavy cloudy conditions such as those encountered in the transit to Antarctica. Thus, Fig. 6 illustrates one of the existing difficulties of aerosol detection and identification in the Southern Ocean using visible-infrared detectors such as MODIS. In this case, the high spatial resolution of the pixels used by the MODIS algorithm (250 m channel, Martins et al., 2002) performs reasonably in detecting clear sky patches. Yet, the aerosol concentrations are not high enough to warrant a method such as the one used by Kaufman et al. (2005) to identify aerosol types. Additional information regarding aerosol identification is needed.

A number of satellite detectors were available at the time of the dust events here studied. In addition to MODIS, we explored the level 2 aerosol retrievals of the following detectors: OMI, PARASOL, MISR and GLAS. Although OMI and PARASOL have been used for aerosol type identification, their retrievals during the period 22 February to 9 March in the Southern Ocean region did not show useful information for this analysis. The MISR detector on-board of Terra has a narrower swath than OMI and PARASOL. Level 2 Aerosol retrievals are reported at $\sim 17 \times 17 \mathrm{~km}$ but the retrieval is carried by aggregating smaller pixels $(170 \times 170 \mathrm{~m})$ and selecting only those where the clear sky confidence is high (Kahn et al., 2005). Thus, Level 2 Aerosol retrievals of non-spherical aerosol fraction are representative of pixels much smaller than those used by OMI and PARASOL. In addition, MISR data is available on the same days and within the same swath of MODIS-Terra. All these features made MISR the tool of choice for aerosol identification in this study.

Although operating a couple of months per year, the GLAS lidar was active during late February and March 2005 and it provided the vertical distribution of aerosols. Because operational problems, the $532 \mathrm{~nm}$ laser was not working properly and did not provide useful profiles. The $1064 \mathrm{~nm}$ laser was operational and it was sensitive to aerosols in clear sky conditions. However, the laser was losing power too and no aerosol layers were identified above clouds in part because the contamination of the return signal from clouds (Steve Pal., GLAS science team member, personal communication, 2009). 

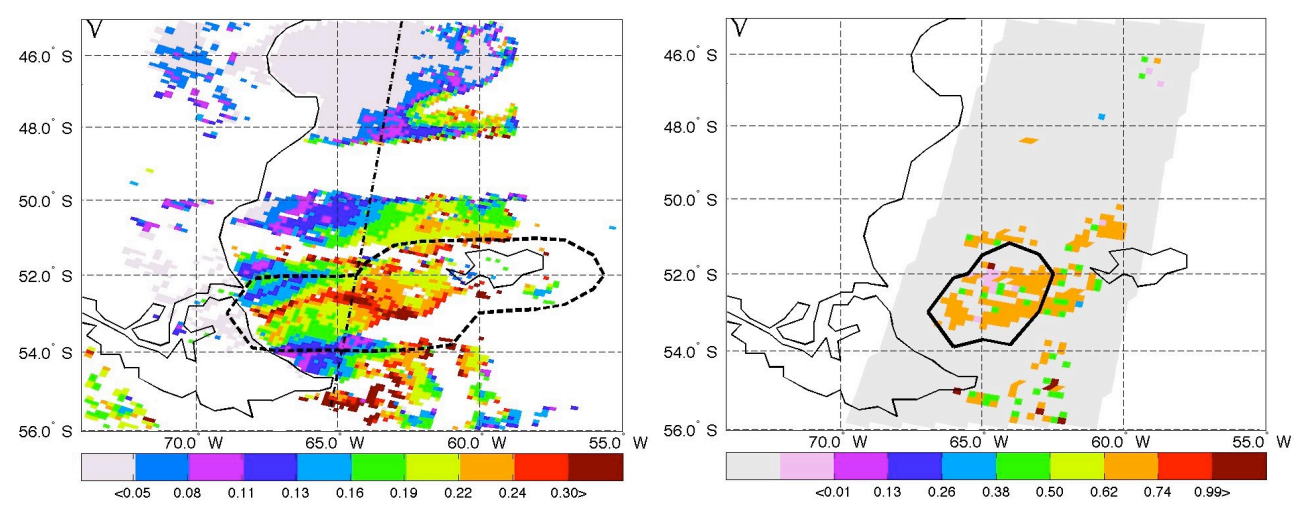

Fig. 7. MODIS-Terra AOTs (left panel) and MISR non-spherical fraction (right) for pixels with AOTs >0.16 (pass time near 13:55 UTC). The MODIS image includes the envelope of pixels witn non-zero dust concentration according to HYSPLIT for a model run unconstrained by surface observations (thick dashed line). Also, the image shows the north-south track of GLAS five hours later. The image on the right shows the envelope of non-zero dust concentrations (solid thick line) for HYPSLIT model run constrained by surface obs.

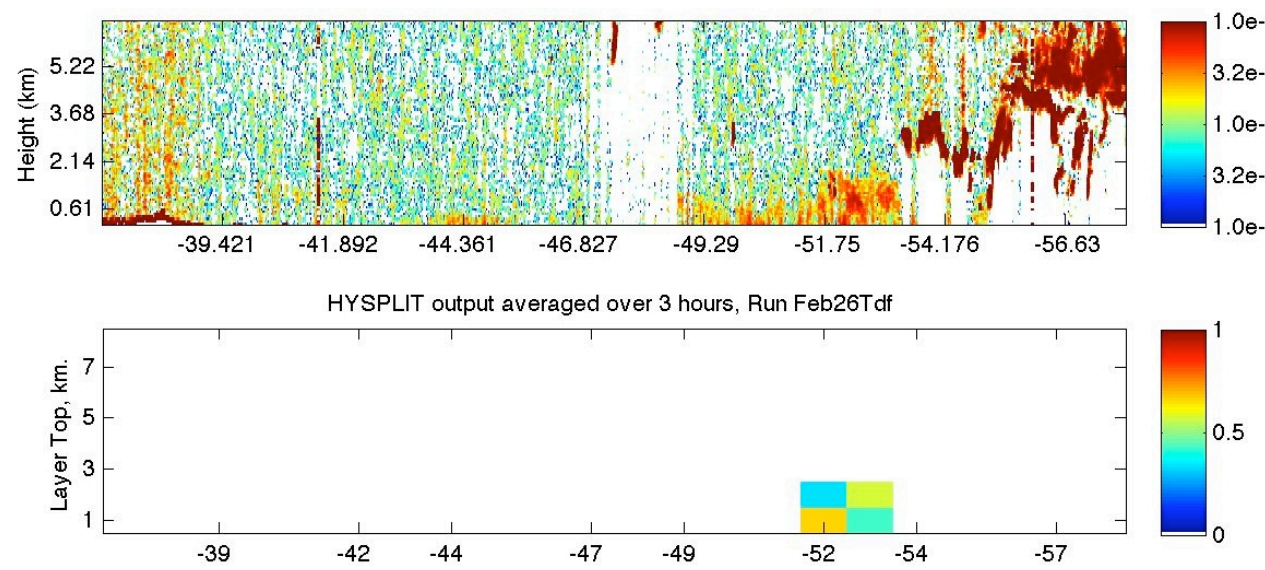

Fig. 8. Top Panel: GLAS 1064nm backscatter profiles for the low $6.6 \mathrm{~km}$. White=no signal, red=clouds, yellow and green; orange=aerosol. Bottom panel: normalized HYSPLIT concentrations for run TdF26, model run constrained by observations.

The next sections show MODIS, MISR and GLAS (when available) observations analyzed jointly with the model outputs for run Feb26TdF.

\subsection{Analysis of case 26 February}

Figures 7 show retrievals for 26 February. Aerosol optical depths from MODIS-Terra are in the left figure and MISR non-spherical AOD fraction on the right. Because MISR is onboard of the Terra satellite, both MODIS and MISR observations are simultaneous. MODIS data is provided in $5 \mathrm{~min}$ utes segments ("granules") and this image shows the aggregation of two consecutive overpasses or orbits. Data of each overpass corresponds to observations at the same local time. The MISR data is only displayed for those pixels with AOTs above 0.16 . Non-spherical retrievals below this threshold are considered unreliable (Kalishnikova and Kahn, 2008). Overlapped to both images is the contour of the dust cloud modeled by HYSPLIT (averaged over the 3 hours closest to the satellite pass). The right hand side shows the contour for the constrained run and the unconstrained run is on the left. The contour displays all pixels with non-zero dust concentration according to the model. The image in the left includes the track of GLAS which flew over at approximately 19:50UTC. The GLAS vertical profiles of backscattering and the respective HSYPLIT output profiles along the GLAS track are shown in Fig. 8. Qualitatively, aerosols can be distinguished by the colors green, yellow and orange colored $\left(\sim 8.10^{-7}\right.$ to $\left.3.10^{-6} 1 / \mathrm{m} . \mathrm{str}\right)$ and clouds are in red. White colors are negative values or no signal return from under the clouds.

By comparing both MODIS and MISR retrievals, there is a clear spatial consistency between the high AOTs and the high values of non-spherical fraction. In addition the location of the dust cloud according to HYSPLIT coincides with the spatial distribution of the aerosol according to both satellites. However, there are notable differences between the constrained and unconstrained model runs. The contour of 

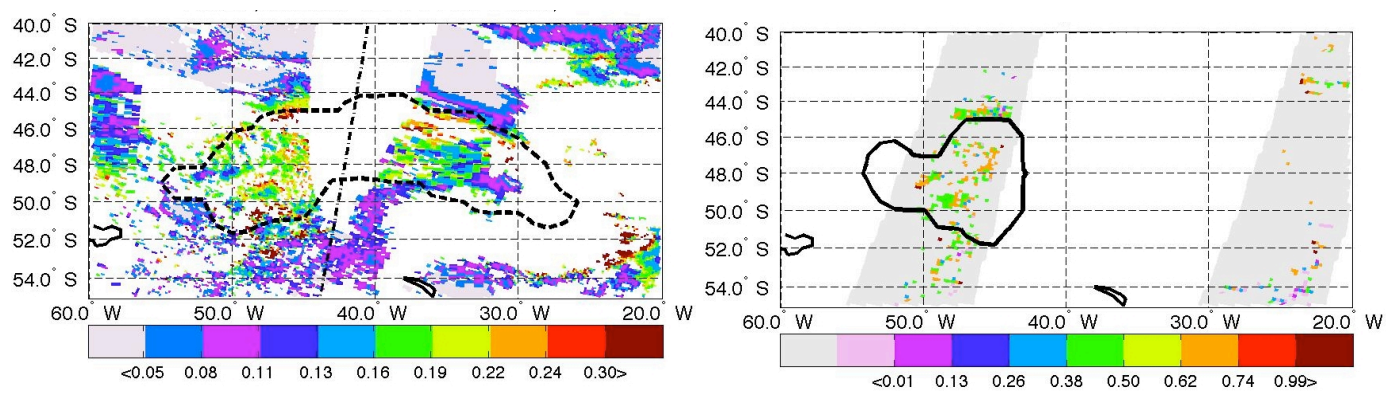

Fig. 9. Same as Fig. 7 but for the day after of the dust event (27 February). GLAS pass (N-S dashed line) was at $\sim 18: 20$ UTC. The MODIS images are composed out of two successive orbits in the region $(\sim 11: 20$ and 13:00 UTC).
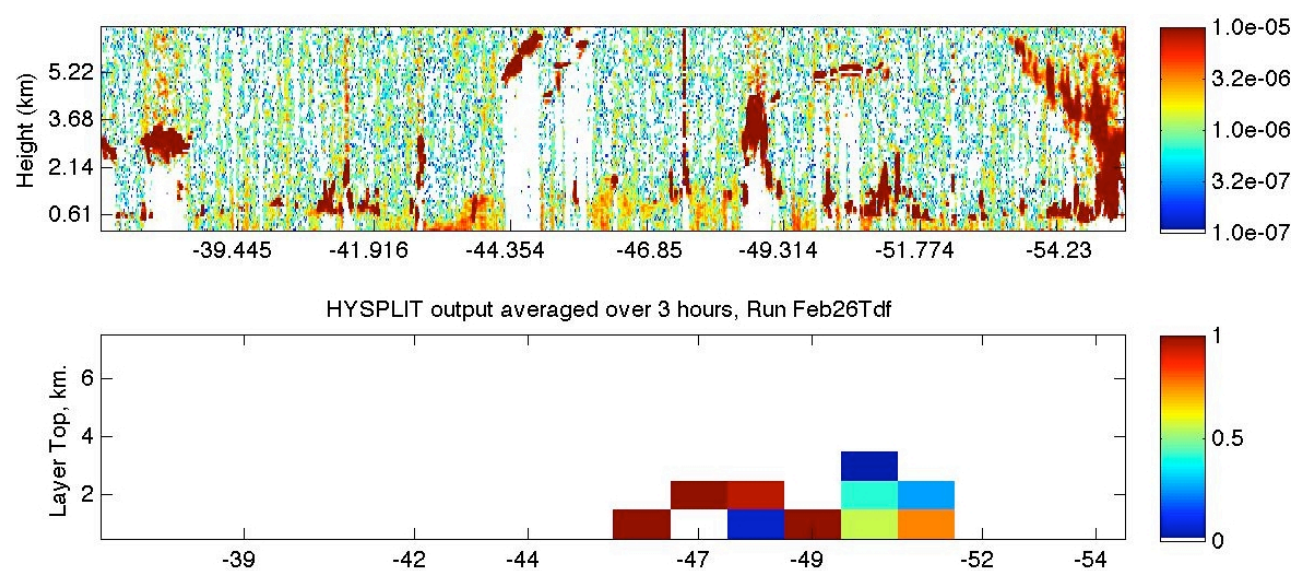

Fig. 10. Same as Fig. 8 but for 27 February. Note that the location of highest backscattering seen by GLAS in the boundary layer ( $\sim 44$ S) does not coincide with location of the dust modeled by HYSPLIT.

the unconstrained run seems to contain most of the MODIS higher optical depths whereas it is not the case for the constrained run. By inspecting and comparing the assimilated data used in the unconstrained run (GDAS) with the surface observations, the latter report visible dust and high winds for fewer hours than the number of hours of high winds in the assimilated data. In other words, the unconstrained run starts to emit dust earlier and for a longer length of time than the constrained run.

The GLAS profile shows high backscattering (orange and yellow) in the bottom $2 \mathrm{~km}$ of the profile and it extends from 49 to $53 \mathrm{~S}$ consistent with MODIS and MISR spatial distribution of the aerosol in the north-south direction. The vertical location of the dust is consistent with the model simulation that places the dust in the bottom two layers of the model (bottom Fig. 8). The MODIS-Aqua pass was closer in time to the GLAS overpass and had similar AOTs and aerosol distribution as derived by MODIS-Terra (not shown).

In summary, on the day of the event MISR, MODIS, GLAS and the model simulation are all consistent in placing the dust in same region and height. This agreement is useful for the analysis of satellite data in the subsequent days where dust concentrations are lower and the dust cloud is more diffuse and difficult to identify just by looking at the spatial pattern.

\subsection{Analysis of the day after the event (27 February)}

Figures 9 and 10 show a set of MODIS, MISR and GLAS images in similar format to Figs. 7 and 8 for the day after of the event (27 February). In this case, the dust cloud has dispersed and it cannot be easily identified in a visible image (not shown) like the day before. Thus all observations need to be considered jointly in order to detect and locate the extension of the dust cloud. In this case, Fig. 9a and b and model contour are consistent too. The MODIS AOTs are higher inside the model contours than the surroundings. In the same area, MISR shows several pixels with an important non-spherical fraction contribution in the total optical depth (ranging 38-74\%). In addition, MISR retrievals are in agreement with the location of the dust cloud according to the model.

The GLAS image (Fig. 10a) shows high aerosol concentrations in the boundary layer as far south as $53 \mathrm{~S}$. The model output places the dust in the boundary layer too in the same area (see the track in Fig. 9a). Further, the north to south 

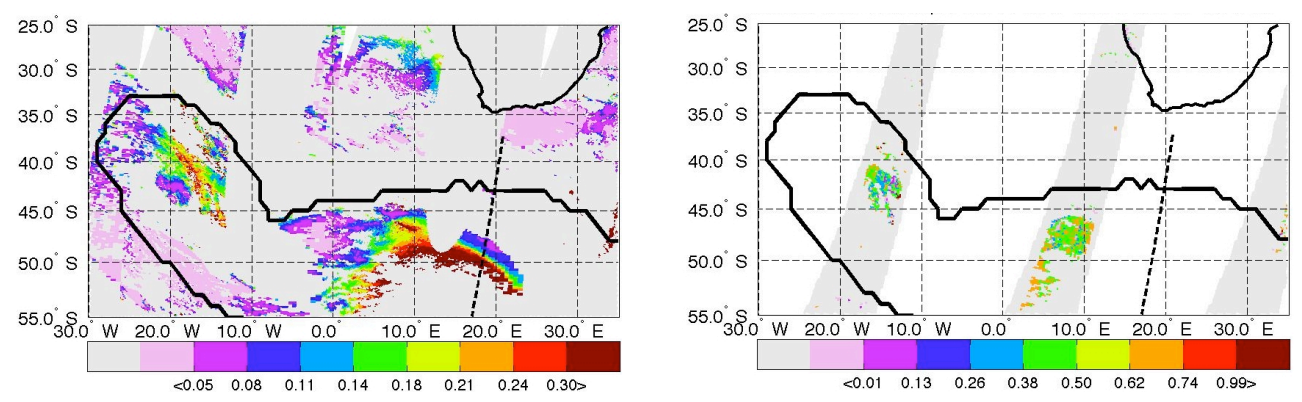

Fig. 11. MODIS-Terra AOTs (left) and MISR non-spherical fraction (right) for 3 March. MODIS images are composites of two consecutive overpasses (at 10:55 and 12:35 UTC). North to South dashed line is the track of GLASS at 14:13 UTC.

extent of the dust cloud agrees with GLAS too although the model does not extend as far north as the GLAS signal suggests. There are some inconsistencies too, note the high backscattering at $44.5 \mathrm{~S}$ does not seem to be dust according to the model.

As noted in the previous sections, the difference in emission schemes in the HYSPLIT runs results in different spatial distribution and reach of the dust cloud. In this case, both constrained and unconstrained runs agree in the location and distribution of dust in the region enclosed by the non-spherical retrievals of MISR ( $50 \mathrm{~W}$ to $45 \mathrm{~W}$ ). However, both runs disagree on the location of the leading (or east) edge of the dust cloud. The difference of emission initiation is more apparent after 24 hours. The MODIS image show a large patch of AOTs ranging $0.16-0.22$ in the $38-32 \mathrm{~W}, 45-$ $49 \mathrm{~S}$ box which agrees with the unconstrained run but it does not agree with the constrained run. This is a demonstration of the effect of the difference in emission conditions as defined by the constrained and unconstrained runs.

When putting all this information together i.e. agreement between model height and location of the dust with aerosol information from the satellites, it becomes apparent that the dust cloud reached the south-central South Atlantic extending from $\sim 45 \mathrm{~S}$ to $50 \mathrm{~S}$ and reaching as far east as $\sim 40 \mathrm{~W}$ or further east. This agrees with an observation of dust previously reported in the same area (Gassó and Stein, 2007).

\subsection{Analysis of days after 27 February}

By 28 February, the simulated dust cloud has extended throughout most of the South Atlantic. However, because the extensive cloudiness, there were very few MODIS and MISR retrievals within. Even when clear sky patches were found by the respective algorithms, they contained small or zero non-spherical fractions and low AOTS (0.05-0.1 range). On 1 and 2 March, there were large clear sky patches within the simulated dust cloud with high AOTs $(0.15-0.25)$. However, none of them contained a high number values of nonspherical fraction. After 4 March, analysis of images and retrievals of subsequent days did not show any positive identification of dust.
On 3 March, however, two large patches of clear sky within the (constrained simulation) dust cloud were located SW of South Africa (35-55 S, 25 W-20E). Optical depths within both patches are well above 0.1 with several pixels above 0.3 (Fig. 11). Further, each of the patches has dozens of contiguous clear sky pixels with a gradual change of AOT, which is a good visual indication of minimal cloud contamination. There were also abundant retrievals of high values of non-spherical fraction (ranging 0.5-0.7) in those clear sky patches. Further, four hours later Aqua (near 13:25 UTC) observed similarly high AOTs in the same two patches (Fig. 12a). Approximately at 14:13 UTC GLAS flew by over the same clear patch observed by Aqua (see track overlap in Fig. 11). The GLAS profile confirms of the presence of abundant aerosol concentration in the boundary layer.

In order to get additional insight of the nature of the high concentration of non-spherical aerosols, a few additional checks were performed. Because cirrus are a common occurrence and can interfere in the MISR aerosol retrieval, their presence in the area was tested. An image of the MODIS (band 26) reflectance at $1.64 \mu \mathrm{m}$ MODIS was generated. This band is particularly sensitive to high altitude cirrus (Ackerman et al., 1998) and to water vapor absorption. If cirrus are present, they scatter back radiation to the sensor. However, if there are no cirrus, the signal is absorbed by the boundary layer water vapor resulting in an almost zero reflectance for this pixel. The corresponding images clearly showed very low and almost zero band 26 reflectances in the clear sky patches where the high AOT were retrieved. This suggests no cirrus contamination. The large size of the patches observed on this day prompted the reexamination of the OMI images which yielded a negative result (i.e. no $\mathrm{AI}>1$ was detected in the area of high values of non-spherical fraction). This is not entirely inconsistent because OMI is not very sensitive to low altitude dust (Mahowald and Dufresne, 2004), which is the case here as the GLAS data for this day indicate.

An additional test was applied using a dust detection method based on IR emissivities (Ackerman, 1997). Because dust has a different spectral emissivities in the 11 and $12 \mu \mathrm{m}$ (Bands 31 and 32 of MODIS), several detection techniques 

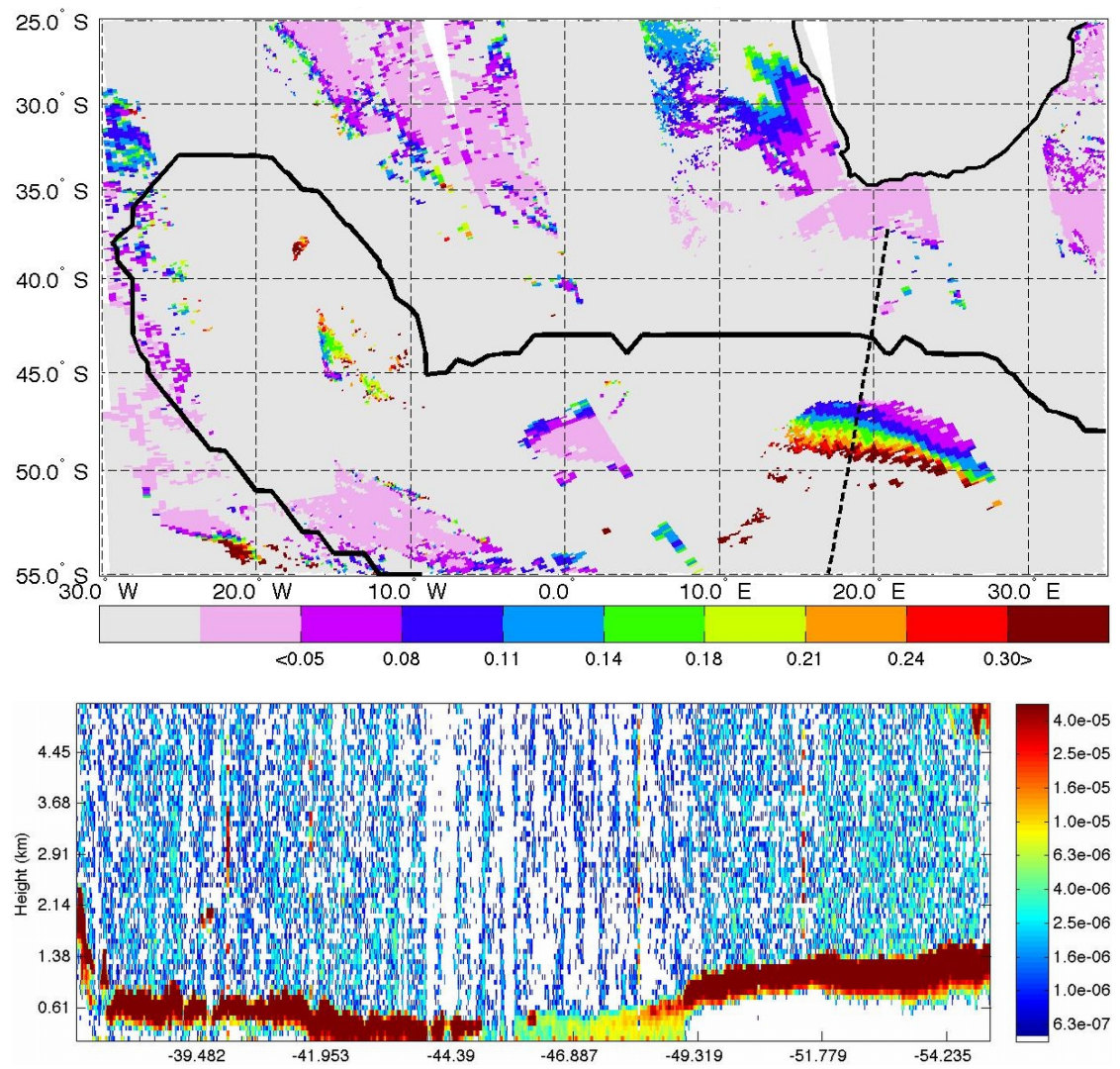

Fig. 12. Top: MODISAqua Aerosol optical depths for 3 March (around 13:25 UTC) with the contour of dust concentration of constrained run Feb26TdF. The dashed line is the GLAS track for an overpass pass at 14:13 UTC. Bottom: the backscattering profile for the track shown in the AOT image and shows that the high optical depths correspond to boundary level aerosols

have been developed based on these IR channels in combination with visible channels (Baddock et al., 2009). In this case only the Ackerman test was applied. The test yielded no identification of dust in the infrared. However, the negative result of this test does not rule out the presence of dust. Since in this case, the aerosol is located in the low $700 \mathrm{~m}$ of the boundary layer (confirmed by GLAS) and the contrast in brightness temperatures may not be enough. Further there have been reports of brightness temperature differences opposite to what the Ackerman et al., 1997 method predicts (Darmenov and Sokolik, 2005).

In summary, the model simulation and MISR nonspherical fraction are consistent in pointing to the presence of dust in this area. MODIS confirms the presence of high concentration of aerosols and they are mostly restricted to the boundary layer. However, other dust detection proxies do not positively associate the aerosol with dust although these tests were not designed for this type of scene (dust over ocean in the boundary layer).

\section{Discussion}

Although ideally more sophisticated techniques (such as isotopic analysis) would be able to trace the sources of dust measured at Concordia, there are a number of observations and modeling features that show a remarkable consistency in showing dust transport to Antarctica. The findings described in the previous sections can be summarized as follows:

1. Identified dust in the Concordia site on 8-9 March 2005 (Fig. 1)

2. Backtrajectory modeling indicates Patagonia as a possible source (Fig. 3).

3. Surface visibility and satellite confirm dust activity in Patagonia (Sect. 3.1) coinciding with the departure of air parcels that arrived to Concordia (backtrajectory analysis)

4. Surface measurements of aerosol absorption in Neumayer show increases on 28 February to 5 and 9 March (Fig. 5).

5. Forward modeling initialized by observed dust sources shows agreement in the timing of arrival of modeled 
dust with the observed increase of dust observations and proxies (model comparison with surface data at Neumayer and Concordia, Sect. 3.4).

6. Satellite observations confirms the presence of dust (traveling in the boundary layer) at least to $\sim 1700 \mathrm{~km}$ east from the source and possibly reaching $\sim 1800 \mathrm{~km} \mathrm{SW}$ of Cape Town, South Africa (Sect. 4).

The interpretation of the different agreements between model and observation does have some weaknesses. Some of tools used here have not been validated. For example, the uncertainties in assimilated winds and in deposition of aerosols have not been properly characterized in HYSPLIT. Thus, because the lack of information of removal processes during transport, the approach used was limited to temporal comparisons (i.e. transit times to Neumayer and Concordia) and quantitative comparisons were avoided when comparing with surface data. Only relative comparisons between normalized concentrations of different model runs were examined. However, in comparing modeled concentration with satellite data, the criterion was to display all areas where dust could have arrived according to the model. Thus the model provided the envelope of maximum extension of the dust cloud and there was no attempt to compare the modeled concentration magnitudes with the satellite data. This assumption was reasonable for the first two days of the event when unknown errors in emission details and winds have not propagated. However, it is not clear the impact of these errors after 5-6 days after emission. An example of the uncertainty in emission conditions is demonstrated in the differences in the propagation and spatial distribution of the dust clouds in constrained and unconstrained model runs (Figs. 7 and 9).

Also, when comparing model outputs with satellite data, the unconstrained model runs compared better with satellite data than the constrained runs. This suggests that surface information can have limited use unless the visibility observations are close to the major sources, unlike the case studied here.

Satellite data has its limitations too. Although aerosol optical depth (particularly from MODIS) is a parameter extensively validated in regimes of biomass burning, dust and pollution aerosols, they have not been validated as extensively in the marine environment in particular at high latitudes. In fact, in the case of MODIS, some biases of AOT retrievals in the marine environment have been noted (Zhang and Reid, 2005; Zhang et al., 2006). Because MODIS data was used in conjunction with MISR retrievals (which uses a different approach than the MODIS retrievals) and in all cases shown here, they showed agreement indicating no particular bias in MODIS AOT. Finally, the MISR non-spherical fraction parameter has not been validated. However, the MISR team has used this parameter to characterize long range transport of Saharan dust (Kalashnikova and Kahn, 2008) with the same approach that was used here.
As it is apparent in Figs. 6,7 and 9, there are several clusters of AOTs in the same range of values as those identified as dust. Likewise with the MISR non-spherical fraction image, there are several spots of high values outside the model contours similar to those associated with the dust cloud. The identification of the dust becomes only apparent when all these pieces of information (model and satellite) are analyzed together. Specifically, it is critical in this analysis the identification of a dust event at its initiation, which allows the correct setup of the model run and obtains an accurate prediction of the location of the dust cloud.

When using OMI data, the rule of thumb for dust detection is $\mathrm{AI}>1$ and values in the range $0-1$ are normally dismissed as not reliable as a dust flag. Reexamination of the OMI AI retrievals for the time period 27 February to 4 March shows an interesting feature. In all clear sky patches where high non-spherical fraction was detected, the corresponding AI for approximately the same area (given the time difference between MISR and OMI passes) was in the 0 to 1 range. This suggests that there was an absorbing agent either in the ocean or the atmosphere. If it was in the atmosphere, it was a low laying and/or low concentration of absorbing aerosols. If it was originating in the ocean, it could be water absorption or absorption by biogenic materials (Omar Torres, OMI Aerosol team member, personal communication, 2009). Although an interesting possibility for further study, this is an analysis that is beyond this work.

The GLAS data provided useful information on the location of the aerosol load in the atmospheric column. A significant amount of dust remains in the boundary layer and for a long distance and it confirms the modeling work of $\mathrm{Li}$ et al, (2008) and Krinner et al, (in press) who found significant transport of dust occurs in the boundary layer. It should be noted, however, because deteriorating laser conditions in GLAS, significant number of profiles in cloudy conditions could not be used. As a result, it is not possible to rule out dust transport above clouds in the free troposphere. Although it is clear that the dust event studied here remained in the boundary layer in the first two days, there are no lidar observations south of $\sim 55 \mathrm{~S}$ that can corroborate the location of the dust in the column. Our model simulation suggests the dust is lifted as it moves south but there is not observable that can verify this. With this regards it is clear that further case studies need to be studied in the CALIPSO (a spaceborne lidar deployed in 2006 i.e. after the dust events studied here) data set.

\section{Conclusions}

The purpose of the paper is to show the difficulty to characterize dust over the Southern Ocean. This effort comprised the joint analysis of surface measurements of aerosols, aerosol dispersion modeling and characterization and tracking of the dust cloud in its transit over the Southern Ocean. 
For the case studied, it is clear that dust emission can occur as far south as latitude $54 \mathrm{~S}$, making the Tierra del Fuego Island the southernmost dust source currently active. Also, it appears that dust from Patagonia reached Antarctica in early March 2005. This is supported by the number of pieces of evidence (listed in Sect. 5) that point to long range transport between the two continents.

Even the combination of information from several satellite observations (many of them considered the best tools for aerosol studies currently) do not permit an unambiguous determination of the aerosol type under observation. As noted through the paper, there are numerous ambiguities in the satellite and modeled data that can yield mixed results in terms of characterizing the transport. Only when modeled and satellite data are interpreted jointly, a more consistent description of the dust cloud becomes apparent.

Also, it is clear from this study that dust from the Patagonia desert reach iron deficient regions in the SO and that much of this dust remains in the boundary layer suggesting the bulk of the dust cloud deposits over the ocean surface.

Finally, this works shows that modern dust activity in Patagonia can reach Antarctica. Thus, by studying current dust transport in the SO, better insights can be gained on the understanding of dynamics and dust deposition in past glacial periods.

Acknowledgements. The PI wishes to thank NASA for providing the satellite data free of charge and in an easy to handle format. Co-author JC carried out the work presented during an internship with NASA Summer Institute. Many thanks to Steve Palm from the GLAS science team, the NOAA/ARL, Dr. Rolf Weller (AWI, Germany) and Irene Barnatán (SMN) for facilitating the access to different model and in-situ data sets.

Edited by: J. Quaas

\section{References}

Ackerman, S. A., Strabala, K. I., Menzel, W. P., Frey, R. A., Moeller, C. C., and Gumley, L. E.: Discriminating clear sky from clouds with MODIS, J. Geophys. Res., 103, 32141-32157,1998

Ackerman, S. A.: Remote sensing aerosols using satellite infrared observations, J. Geophys. Res., 102, 17069-17079,1997.

Baddock, M. C., Bullard, J. C., and Bryant, R. G.: Dust source identification using MODIS: a comparison of techniques applied to the Lake Eyre Basin, Australia. Remote Sens. Environ., 113, 1511-1523. doi:10.1016/j.rse.2009.03.002, 2009.

Baker, A. R., Jickells, T. D., Witt, M., and Linge, K. L.: Trends in the solubility of iron, aluminium, manganese and phosphorus in aerosol collected over the Atlantic Ocean, Mar. Chem., 98, 4358, 2006.

Basile, I., Grousset, F. E., Revel, M., Petit, J. R., Biscaye, P. E., and Barkov, N. I.: Patagonian origin of glacial dust deposited in East Antarctica (Vostok and Dome C) during glacial stages 2, 4 and 6, Earth Planet. Sci. Lett., 146, 573-589, 1997

Bergametti, G., Remoudaki, E., Losno, R., Steiner, E., Chatenet, B. et al.: Sources, transport and deposition of atmospheric phospho- rus over the northwestern Mediterranean. J. Atmos. Chem., 14 , 501-513, 1992.

Becagli S., Castellano, E., Cerri, O., Chiari, M., Lucarelli, F., Marino, F., Morganti, A., Nava, S., Rugi, F., Severi, M., Traversi, R., Vitale, V., and Udisti, R.: All year round background aerosol at Dome C (Antarctica): Chemical composition of size-segregated samples collected during the 2004-05 campaign, edited by: Colacino, M. and Ravanelli, C., Conference Proceedings, XI Workshop Italian Research on Antarctic Atmosphere, SIF Bologna, Italy, 17-42, 2009.

Behrenfeld, M. J., O’Malley, R. T., Siegel, D. A., et al.: Climate driven trends in contemporary ocean productivity, Nature, 444, 752-755, 2006.

Bigler, M., Röthlisberger, R., Lambert, F., Stocker, T. F., and Wagenbach, D. : Aerosol deposited in East Antarctica over the last glacial cycle: Detailed apportionment of continental and sea salt contributions, J. Geophys. Res., 111, D08205, doi:10.1029/2005JD006469, 2006

Diner, D. J., Abdou, W. A., Conel, J. E., Crean, K. A., Gaitley, B. J., Helmlinger, M., Kahn, R. A. Martonchik, J. V., and Pilorz, S. H.: MISR aerosol retrievals over southern Africa during the SAFARI-2000 dry season campaign, Geophys. Res. Lett., 28, 3127-3130, 2001.

Draxler, R. R. and Hess, G. D.: An overview of the HYSPLIT_4 modelling system for trajectories, dispersion, and deposition, Australian Meteorological Magazine, 47, 295-308,1998.

Draxler, R. R., Gillette, D. A. Kirkpatrick, J. S. and Heller, J.: Estimating $\mathrm{PM}_{10}$ air concentrations from dust storms in Iraq, Kuwait, and Saudi Arabia, Atmos. Environ., 35, 4315-4330, 2001.

Draxler, R. R. and Rolph, G. D.: HYSPLIT (HYbrid Single-Particle Lagrangian Integrated Trajectory) Model access via NOAA ARL READY Website, NOAA Air Resour. Lab., Silver Spring, Md., available online at: http://www.arl.noaa.gov/ready/hysplit4.html, 2003.

Darmenov, A. and Sokolik, I. N.: Identifying the regional thermalIR radiative signature of mineral dust with MODIS, Geophys. Res. Lett., 32, L16803, doi:10.1029/2005GL023092, 2005.

del Valle, H. F., Elissalde, N. O., Gagliardini, D. A., and Milovich, J.: Status of desertification in the Patagonian region: Assessment and mapping from satellite imagery, Arid Soil Res. Rehab., 12(2), 1-27, 1998.

Dubovik, O., Holben, B. N., Eck, T. F., Smirnov, A., Kaufman, Y. J., King, M. D., Tanré, D., and Slutsker, I.: Variability of absorption and optical properties of key aerosol types observed in 5 worldwide locations, J. Atmos. Sci., 59, 590-608, 2002.

Escudero, M., Stein, A., Draxler, R. R., Querol, X., Alastuey, A., Castillo, S., and Avila, A.: Determination of the contribution of northern Africa dust source areas to $\mathrm{PM}_{10}$ concentrations over the central Iberian Peninsula using the Hybrid Single-Particle Lagrangian Integrated Trajectory model (HYSPLIT) model, J. Geophys. Res.-Atmos., 111(D6), D06210, doi:10.1029/2005JD006395, 2006.

Fattori I., Becagli, S., Bellandi, S., Innocenti, M., Mannini, A., Severi, M., Vitale, V., and Udisti, R.: Chemical composition and physical features of summer aerosol at Terra Nova Bay and Dome C (Antarctica), J. Environ .Monitor., 7(12), 1265-1274, 2005.

Fiebig, M., Lunder, C. R., and Stohl, A.: Tracing biomass 
burning aerosol from South America to Troll Research Station, Antarctica, Geophys. Res. Lett., 36, L14815, doi:10.1029/2009GL038531,2009

Fischer, H., Fundel, F., Ruth, U., Twarloh, B., Wegener, A., Udisti, R., Becagli, S., Castellano, E., Morganti, A., Severi, M., Wolff, E. W., Littot, G. C., Röthlisberger, R., Mulvaney, R., Hutterli, M. A., Kaufmann, P., Federer, U., Lambert, F., Bigler, M., Hansson, M., Jonsell, U., De Angelis, M., Boutron, C., SiggaardAndersen, M.-L., Steffensen, J. P., Barbante, C., Gaspari, V., Gabrielli, P., and Wagenbach, D.: Reconstruction of millennial changes in dust emission, transport and regional sea ice coverage using the deep EPICA ice cores from the Atlantic and Indian Ocean sector of Antarctica, Earth Planet. Sci. Lett., 260, 340354, 2007.

Gassó, S. and Stein, A. F. : Does dust from Patagonia reach the sub-Antarctic Atlantic Ocean?, Geophys. Res. Lett., 34, L01801, doi:10.1029/2006GL027693, 2007.

Gaiero, D. M., Probst, J. L., Depetris, P. J. , Bidart, S. M. and Leleyter, L. : Iron and other transition metals in Patagonian riverborne and windborne materials: Geochemical control and transport to the southern South Atlantic Ocean, Geochim. Cosmochim. Acta, 67(19), 3603-3623, 2003.

Gaiero, D. M.: Dust provenance in Antarctic ice during glacial periods: From where in southern South America?, Geophys. Res. Lett., 34, L17707, doi:10.1029/2007GL030520, 2007.

Guo, Y., Chang, E. K. M., and Leroy, S. S. : How strong are the Southern Hemisphere storm tracks?, Geophys. Res. Lett., 36, L22806, doi:10.1029/2009GL040733,2009.

Herman, M., Deuz' e, J.-L., Marchand, A., Roger, B., and Lallart, P.: Aerosol remote sensing 5 from POLDER//ADEOS over the ocean: Improved retrieval using a nonspherical particle model, J. Geophys. Res., 110, D10S02, doi:10.1029/2004JD004798, 2005.

Jickells, T. D., An, Z. S., Andersen, K. K., Baker, A. R., Bergametti, G., Brooks, N., Cao, J. J., Boyd, P. W., Duce, R. A., Hunter, K. A., Kawahata, H., Kubilay, N., Laroche, J., Liss, P. S., Mahowald, N., Prospero, J. M., Ridgwell, A. J., Tegen, I., and Torres, R.: Global iron connections between desert dust, ocean biogeochemistry, and climate, Science, 308, 67-71, 2005.

Jones, D. A. and Simmonds, I.: A climatology of Southern Hemisphere extratropical cyclones. Clim. Dynam., 9, 131-145, 1993

Isla, F. I., Vilas, F. E., Bujalesky, G. G., Ferrero, M., Gonzalez Bonorino, G., and Arche Miralles, A.: Gravel drift and wind effects on the macrotidal San Sebastian Bay, Tierra del Fuego, Argentina. Mar. Geol., 97:211-224,1991

Kahn, R. A., Gaitley, B., Martonchik, J., Diner, D., Crean, K., and Holben, B.: MISR global aerosol optical depth validation based on two years of coincident AERONET observations. J. Geophys. Res., 110, D10S04, doi:10.1029/2004JD004706,2005

Kalashnikova, O. V. and Kahn, R. A.: Mineral dust plume evolution over the Atlantic from MISR and MODIS aerosol retrievals, J. Geophys. Res., 113, D24204, doi:10.1029/008JD010083,2008.

Kanamitsu, M.: Description of the NMC global data assimilation and forecast system, Weather Forecast., 4, 335-342,1989.

Kaufman, Y. J., Tanré, D., and Boucher, O.: A satellite view of aerosols in the climate system, Rev.. Nature, 419, 215-223,2002.

Kaufman, Y. J., Koren, I. , Remer, L. A., Tanré, D., Ginoux, P., and Fan, S.: Dust transport and deposition observed from the Terra-Moderate Resolution Imaging Spectroradiometer
(MODIS) spacecraft over the Atlantic Ocean. J. Geophys. Res., 110, D10S12, doi:10.1029/2003JDO04436, 2005

Kalnay, E., Kanamitsu, M., Kistler, R., et al.: The NCEP/NCAR 40year reanalysis project, Bull. Am. Meteorol. Soc., 77, 437-471, 1996.

King, J. C. and Turner, J.: Antarctic meteorology and climate, Cambridge University Press, UK, ISBN 0-521-46560-5, 1997

Kleidman, R. G., O’Neill, N. T., Remer, L. A., Kaufman, Y. J., Eck, T. F., T. F., Tanré, D., Dubovik, O., and Holben, B. N.: Comparison of Moderate Resolution Imaging Spectroradiometer (MODIS) and Aerosol Robotic Network (AERONET) remotesensing retrievals of aerosol fine mode fraction over ocean, J. Geophys. Res., 110, D22205, doi:10.1029/2005JD005760,2005

König-Langlo, G. and Weller, R.: The GAW Global Observatory Neumayer, Antarctica, World Meteorological Organzation. The German Contribution to the WMO GAW Programme, 167, 1620, 2006.

Krinner, G., Petit, J.-R., and Delmonte, B.: Altitude of atmospheric tracer transport towards Antarctica in present and glacial climate. Quat. Sci. Rev., 29(1-2), 274-284, doi:10.1016/j.quascirev.2009.06.020, 2010

Labraga, J.C. : On extreme winds in Pampa del Castillo plateau, Patagonia Argentina, with reference to wind farms settlement. J. App. Meteo., 33, (1), 85-95,1994.

Lambert, F., Delmonte, B., Petit, J.-R., Bigler, M., Kaufmann, P., Hutterli, M. A., Stocker, T. F., Ruth, U., Steffensen, J. P., and Maggi, V.: Dust-climate couplings over the past 800,000 years from the EPICA Dome C ice core, Nature, 452, 616-619, doi:10.1038/nature06763, 2008.

Levitus, S., Antonov, J., and Boyer, T.: Warming of the world ocean, : 1955-2003, Geophys. Res. Lett., 32, L02604, doi:10.1029/2004GL021592, 2005.

Li, F., Ginoux, P., and Ramaswamy, V.: Distribution, transport, and deposition of mineral dust in the Southern Ocean and Antarctica: Contribution of major sources, J. Geophys. Res., 113, D10207, doi:10.1029/2007JD009190,2008.

McConnell, J. R. , Aristarain, A. J., Banta, J. R., Edwards, P. R., and Simoes, J. C.: 20th Century Doubling in Dust Archived in an Antarctic Peninsula Ice Core PZrallels Climate Change and Desertification in South America, Proc. Natl. Acad. Sci., 104(14), 5732-5748. doi:10.1073pnas.0607657104, 2008.

Mallet, M., Chami, M. ,Gentili, B., Sempéré, R., and Dubuisson, P.: Impact of sea-surface dust radiative forcing on the oceanic primary production: A $1 \mathrm{D}$ modeling approach applied to the West African coastal waters, Geophys. Res. Lett., 36, L15828, doi:10.1029/2009GL039053, 2009.

Mahowald, N. M., Sebastian, E., Luo, C., et al.: Atmospheric iron deposition: global distribution, variability, and human perturbations, Ann. Rev. Mar. Sci., 1, 245-278, 2009.

Mahowald, N. M., Ballantine, J. A., Feddema, J., and Ramankutty, N.: Global trends in visibility: implications for dust sources, Atmos. Chem. Phys., 7, 3309-3339, 2007

Mahowald, N. and Dufresne, J.-L.: Sensitivity of TOMS AI to PBLH: Implications for detection of mineral aerosol sources, 31, L03103, doi:10.1029/2003GL018865, 2004.

Marino, F., Castellano, E., Ceccato, D., De Deckker, P., Delmonte, B., Ghermandi, G., Maggi, V., Petit, J., Revel-Rolland, M., and Udisti, R.: Defining the geochemical composition of the epica dome $\mathrm{c}$ ice core dust during the last glacial- 
interglacial cycle, Geochem. Geophys. Geosyst., 9, Q10018, doi:10.1029/2008GC002023, 2008.

Marino, F., Calzolai, G., Caporali, S., Castellano, E., Chiari, M., Lucarelli, F., Maggi, V., Nava, S., Sala, M., Udisti, R.: PIXE and PIGE techniques for the analysis of Antarctic ice dust and continental sediments, Nucl. Instr. Meth. Phys. Res. B, 266, 23962400. doi:10.1016/j.nimb.2008.03.029., 2008b.

Martins, J. V., Tanré, D., Remer, L. A., Kaufman, Y. J., Mattoo, S., and Levy, R: MODIS cloud screening for remote sensing of aerosol over oceans using spatial variability. Geophys. Res. Lett., 29(12), 8009, doi:10.1029/2001GL01352, 2002.

Martin, J. H. : Glacial-Interglacial $\mathrm{CO}_{2}$ Change: The Iron Hypothesis, Paleoceanography, 5, 1-13,1990.

Miller, R. L., Tegen, I., and Perlwitz, J.: Surface radiative forcing by soil dust aerosols and the hydrologic cycle, J. Geophys. Res., 109, D04203, doi:10.1029/2003JD004085, 2004.

Morganti, A., Becagli, S., Castellano, E., Severi, M., Traversi, R., and Udisti, R.: An improved flow analysis-ion chromatography method for determination of cationic and anionic species at trace levels in Antarctic ice cores, Anal. Chim. Acta, 2007, 603, 190198, 2007.

Okin, G. S., Mahowald, N., Chadwick, O. A., and Artaxo, P.: Impact of desert dust on the biogeochemistry of phosphorus in terrestrial ecosystems, Global Biogeochem. Cy., 18, GB2005, doi10.1029/2003GB002145, 2004.

Ruth, U., Barbante, C., Bigler, M., Delmonte, B., Fischer, H., Gabrielli, P., et al.: Proxies and measurement techniques for mineral dust in Antarctic ice cores, Environ. Sci. Tech., 42, 56755681, 2008.

Petit, J. R., Jouzel, J., Raynaud, D., Barkov, N. I., Barnola, J.-M., Basile, I., Bender, M., Chappellaz, J., Davis, M., Delaygue, G., Delmotte, M., Kotlyakov, V. M., Legrand, M., Lipenkov, V. Y., Lorius, C., Pepin, L., Ritz, C., Saltzman, E., Stievenard, M.: Climate and atmospheric history of the past 420000 years from the Vostok ice core, Antarctica, Nature, 399, 429-436,1999.

Pereira E. B., Evangelista, H., Pereira, K. C. D., Cavalcanti, I. F. A., and Setzer, A. W.: Apportionment of black carbon in the South Shetland Islands, Antarctic Peninsula, J. Geophys. Res., 111, D03303, doi:10.1029/2005JD006086, 2006.

Remer, L. A., Kaufman, Y. J., Tanre, D., Mattoo, S., Chu, D. A., Martins, J. V., Li, R.-R., Ichoku, C., Levy, R. C., Kleidman, R. G., Eck, T. F., Vermote, E., and Holben, B. N.: The MODIS aerosol algorithm, products and validation, J. Atmos. Sci., 62(4), 947-973, 2005.

Sarmiento, J. L. and Gruber, N.: Ocean Biogeochemical Dynamics, Princeton University Press, Princeton, NJ, USA, 526 pp., 2006.

Sala M., Delmonte, B., Frezzotti, M., Proposito, M., Scarchilli, C., Maggi, V., Artioli, G., Dapiaggi, M., Marino, F., Ricci, P. C., De Giudici, G.: Evidence of calcium carbonates in coastal (Talos Dome and Ross Sea area) East Antarctica snow and firn: environmental and climatic implications, Earth Planet. Sci. Lett., 271, 43-52, 2008.

Spinhirne, J. D., Palm, S. P., Hart, W. D., Hlavka, D. L., and Welton, E. J.: Cloud and aerosol measurements from GLAS: Overview and initial results, Geophys. Res. Lett., 32, L22S03, doi:10.1029/2005GL023507, 2005.

Sokolik, I., Winker, D. M., Bergametti, G., Gillette, D. A., Carmichael, G., and co-authors: Outstanding problems in quantifying the radiative impact of mineral dust, J. Geophys. Res., 106,
18015-18028, 2001.

Swap, R., Garstang, M., Greco, S., Talbot, R., and Kallberg, P.: Saharan Dust in the Amazon Basin, Tellus, v. 44B, 133-149, 1992.

Takahashi, T., Sutherland, S. C., Wanninkhof, R., Sweeney, C., et al.: Climatological mean and decadal changes in surface ocean pCO2 , and net sea-air CO2 ?ux over the global oceans, DeepSea Res. II, 56, 554-577, doi:10.1016/j.dsr2.2008.12.009, 2009.

Tegen, I., Lacis, A. A., and Fung, I.: The influence of mineral aerosols from disturbed soils on the global aerosol radiation budget, Nature, 380, 419-422, 1996.

Torres O., Tanskanen, A., Veihelmann, B., Ahn, C., Braak, R., Bhartia, P. K., Veefkind, P., and Levelt, P.: Aerosols and surface UV products from Ozone Monitoring Instrument observations: An overview, J. Geophys. Res., 112, D24S47, doi:10.1029/2007JD008809, 2007.

Udisti, R., Becagli, S., Benassai, S., Castellano, E., Fattori, I., Innocenti, M., Migliori, A., and Traversi, R.: Atmosphere-snow interaction by a comparison between aerosol and uppermost snowlayers composition at Dome C, East Antarctica, 39, 2005, Ann. Glaciol., 53-61, 2004.

Vilas, F., Arche, A., Ferrero, M., and Isla, F.: Subantarctic macrotidal flats, cheniers and beaches in San Sebastián Bay, Tierra del Fuego, Argentina, Mar. Geol., 160, 301-326, 1999.

Watson, A., Bakker, D., Ridgwell, A., Boyd, P., and Law, C.: Effect of iron supply on Southern Ocean $\mathrm{CO} 2$ uptake and implications for glacial atmospheric $\mathrm{CO}_{2}$, Nature, 407, 730-733,2000.

Weller, R. and Lampert, A.: Optical properties of tropospheric aerosol and sulfate scattering efficiency measured at Neumayer Station, Antarctica. Online supplement to Weller and Lampert, 2000b available online at Publishing Network for Geoscientific \& Environmental Data, http://doi.pangaea.de/10.1594/ PANGAEA.695429, doi:10.1594/PANGAEA.695432, 2008a.

Weller, R. and Lampert, A: Optical properties and sulfate scattering efficiency of boundary layer aerosol at coastal Neumayer Station, Antarctica. J. Geophy. Res, 113, D16208, doi:10.1029/2008JD009962, 2008b.

Wolff, E. W., Fischer, H., Fundel, F., Ruth, U., Twarloh, B., Littot, G. C., Mulvaney, R., Röthlisberger, R., et al.: Southern ocean sea-ice extent, productivity and iron flux over the past eight glacial cycles, Nature, 440, 491-496, 2006.

Xian, P., Reid, J. S. , Turk, J. F., Hyer, E. J., and Westphal, D. L., Impact of modeled versus satellite measured tropical precipitation on regional smoke optical thickness in an aerosol transport model, Geophys. Res. Lett., 36, L16805, doi:10.1029/2009GL038823, 2009.

Yu, H., Chin, M., Remer, L., Kleidman, R., Bellouin, N., Bian, H., and Dieh, T.: Variability of marine aerosol fine-mode fraction and estimates of anthropogenic aerosol component over cloud-free oceans from the Moderate Resolution Imaging Spectroradiometer (MODIS), J. Geophys. Res., 114, D10206, doi10.1029/2008JD010648, 2009.

Zhang, J., Reid, J. S., and Holben, B. N.: An analysis of potential cloud artifacts in MODIS over ocean aerosol optical thickness products, Geophys. Res. Lett., 32, L15803, doi:10.1029/2005GL023254, 2005.

Zhang, J. and Reid., J. S.: MODIS Aerosol Product Analysis for Data Assimilation: Assessment of Level 2 Aerosol Optical Thickness Retrievals, J. Geophys. Res., 111, D22207, doi:10.1029/2005JD006898, 2006. 